
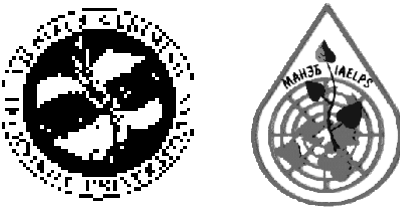

\title{
MIGRATION OF RADIONUCLIDES IN ARABLE LAND OF LITHUANIA
}

\author{
Jadvyga Lubyte், Antanas Antanaitis \\ Lithuanian Institute of Agriculture, Agrochemical Research Centre \\ Savanoriu pr. 287, LT-50127 Kaunas-9, Lithuania \\ E-mail: analize@agrolab.lt
}

Received 2 Jun 2002; Accepted 26 Jun 2002

\begin{abstract}
The paper presents the investigation data on soil contamination by Cs and Sr during the period 1974-2000 in various climatic zones and geographical locations for various granulometric and mineralogic composition of the soil and also for different mineralogical rock composition. The data concerning the accumulation of these elements, their perpendicular distribution before and after the Chernobyl Atomic Power Plant (ChAPP) accident. Besides, the influence of long term fertilization by various NPK rates on the amounts of radionuclides in the soil is presented.

It is determined that before the ChAPP accident an average activity of ${ }^{137} \mathrm{Cs}$ and ${ }^{90} \mathrm{Sr}$ was $6,8 \pm 1,8 \mathrm{~Bq} \cdot \mathrm{kg}^{-1}$ and $5,3 \pm 1,2 \mathrm{~Bq} \cdot \mathrm{kg}^{-1}$, respectively. The radioactivity of peat soils was 2-5 times larger than that of mineral soils. After the accident in the ChAPP the amount of ${ }^{90} \mathrm{Sr}$ in control plots, in the layer of $0-20 \mathrm{~cm}$ has not changed. In some fields an average amount of ${ }^{137} \mathrm{Cs}$ is $6,7-28,5 \mathrm{~Bq} \cdot \mathrm{kg}^{-1}$. Larger concentrations of radionuclides were detected in the southeastern, southern and western regions of Lithuania.

The amount of ${ }^{137} \mathrm{Cs}$ in the upper soil layer in the western region of Lithuania was 1,1-1,2 times larger than in the layer of 5-20 cm, and 1,3-2,5 times larger than in the layer of $20-40 \mathrm{~cm}$. Distinction is not so noticeable in the middle and eastern regions of Lithuania, correspondingly 1,1-1,2 and 1,2-1,6 times.

Migration of ${ }^{90} \mathrm{Sr}$ and ${ }^{137} \mathrm{Cs}$ from the soil to plants varies and depends on soil properties and types of plants. The coefficients of ${ }^{137} \mathrm{Cs}$ and ${ }^{90} \mathrm{Sr}$ movement from the soil to plants were $0,24-0,53$ and $0,37-0,87$, respectively.

In most cases long term fertilization had no influence on ${ }^{90} \mathrm{Sr}$ and ${ }^{137} \mathrm{Cs}$ accumulation and migration in the soil.
\end{abstract}

Keywords: soil, radionuclide, ${ }^{137} \mathrm{Cs},{ }^{90} \mathrm{Sr}$, migration, Chernobyl Atomic Power Plant (ChAPP).

\section{Introduction}

The sources of radioactive substances can be of a natural and artificial origin. The use of nuclear power in national economy is inevitably connected with prevalence of radioactive substances in the biosphere. When a nuclear reactor is working, radioactive substances are thrown into the atmosphere gradually and it is possible to control or even to regulate it. In the case of an accident, radioactive substances in a solid, liquid or gaseous state are thrown out suddenly.

Due to the most intensive nuclear explosion tests of the $6^{\text {th }}-7^{\text {th }}$ decades, huge amounts of artificial radionuclide, including $1,3 \cdot 10^{8}{ }^{137} \mathrm{Cs}$ [1] were released into the environment. An average amount of ${ }^{137} \mathrm{Cs}$ is between $1,1 \mathrm{kBq} \cdot \mathrm{m}^{-2}$ and $2,2 \mathrm{kBq} \cdot \mathrm{m}^{-2}$ on the surface of Lithuanian soil because of global shedding of radioactive substances [2].

During the accident of the ChAPP a large area of Europe was contaminated by the products of nuclear fuel and nuclear reaction. According to the data of radioactive contamination after the ChAPP accident, the level of ${ }^{137} \mathrm{Cs}$ increased by $40 \mathrm{kBq} \cdot \mathrm{m}^{-2}$ in about $2 \%$ of the European territory and even by $1480 \mathrm{kBq} \cdot \mathrm{m}^{-2}$ in about $0,03 \%$ of the European territory. Contamination exceeded the level of $20 \mathrm{kBq} \cdot \mathrm{m}^{-2}$ in an area of about $6 \%$ of the European territory. The total ${ }^{137} \mathrm{Cs}$ in Europe is about $8 \cdot 10^{16} \mathrm{~Bq}$, part of it $\left(7 \cdot 10^{16} \mathrm{~Bq}\right)$ resulted from the ChAPP accident.

The content of ${ }^{137} \mathrm{Cs}$ in Lithuania varied from 0 to $8340 \mathrm{Bqm}^{-2}$, its average was $310 \mathrm{~Bq} \cdot \mathrm{m}^{-2}$ [3]. Some references direct that the amounts of ${ }^{90} \mathrm{Sr}$ and ${ }^{137} \mathrm{Cs}$ thrown out into the environment by the Ignalina Atomic Power Plant are insignificant and the contamination in the territory of Lithuania will not be increased [4].

The physical and chemical properties of the soil, such as the reaction, humus content, soil genesis and sorption capacity, have a considerable influence on the accumulation and migration of radionuclides [5-8].

\section{Methods of analysis}

Investigations of radionuclide contamination in various soils of Lithuania and its migration from the soil to 
plants have been carried out since 1974. 26 plots (since 1979 ) and 30 plots of $50 \times 50 \mathrm{~m}$ (since 1986) were selected for controlling radionuclide contamination in various climatic zones and in different soils.

Contamination of the ground in Lithuania by ${ }^{90} \mathrm{Sr}$ and ${ }^{137} \mathrm{Cs}$ was not investigated sufficiently and there was also a lack of publications. That is why, during the period 1980-1983, 395 soil samples which reflect the Lithuanian soils were collected and analysed.

Formation of soils with different properties occured due to different soil-formation rocks $(56 \%$ of moraine, $18 \%$ of glacial lacustrine, $14 \%$ of fluvoglacial) under the influence of various soil-formation factors. A widespread type of soil in Lithuania is sod podzolic $28,8 \%$, gleyic sod podzolic and gleyic $-23,6 \%$, sodgleyic and gleyic - $17 \%$.

According to the FAO UNESCO ISRIC classification, the soil in West Lithuania is mostly dystric albeluvisols, in plain areas-gleyic albeluvisols, in East Lithuania-gleyic calcaric luvisols. Gleyic calcaric cambisols and gleyic calcaric luvisols and in some places calcaric luvisols, prevail in middle Lithuania. Gleysols and peat-soil prevail in lowlands.

The Nemunas valley was investigated in 1994 because of contamination by ${ }^{90} \mathrm{Sr}$ and ${ }^{137} \mathrm{Cs}$. Quite a large area in the Nemunas delta is covered with fluvisols.

Since 1986 joint soil samples (from 5 places) have been taken from the layers of $0-20 \mathrm{~cm}$ and $20-40 \mathrm{~cm}$ in pastures and from those of $0-5,5-20 \mathrm{~cm}$ in meadows.
The samples were collected in Skèmiai, Kriūkai and Rumokai fertilization trials conducted by the Agrochemical Research Centre. A crop rotation (of 28 years) fertilization trial was carried out in Skèmiai, Radviliškis district, on the Endocalcari-Endohypogleyic Cambisoil. Radionuclides were determined in the samples of 2 replications of untreated and $\mathrm{N}_{240} \mathrm{P}_{192} \mathrm{~K}_{192}$ variants. The Kriūkai trial (in Šakiai district) was established on a Endocalcari-Endohypogleyic Cambisoils in 1990. The samples were taken from 3 replications of 2 treatments: from untreated and $\mathrm{N}_{120} \mathrm{P}_{180} \mathrm{~K}_{180}$ variants trials were carried out at the Rumokai (Vilkaviškis district) station of the Lithuanian Institute of Agriculture on a limnoglace silty Calc(ar)I-Epihypogleyic Luvisoils with untreated and $\mathrm{N}_{180} \mathrm{P}_{180} \mathrm{~K}_{180}$ variants. The samples of all the fertilization trials were taken from the layers of 0-20, 20-40, 40-60 and 60-90 cm. ${ }^{90} \mathrm{Sr}$ and ${ }^{137} \mathrm{Cs}$ were determined in soil samples by the radiochemical method: ${ }^{90} \mathrm{Sr}$ - by the daughter product ${ }^{90} \mathrm{Y},{ }^{137} \mathrm{Cs}-$ by the method with stibium iodide [9].

Measurements of sediment activity were carried out by the equipment UMF-6 (with a low background) with the counter SB5B. Repeatibility is $25 \%$.

\section{Results and discussion}

The scheme of sampling points is presented in Fig 1. As it is shown in Fig 1, most of them are near the Ignalina Atomic Power Plant.

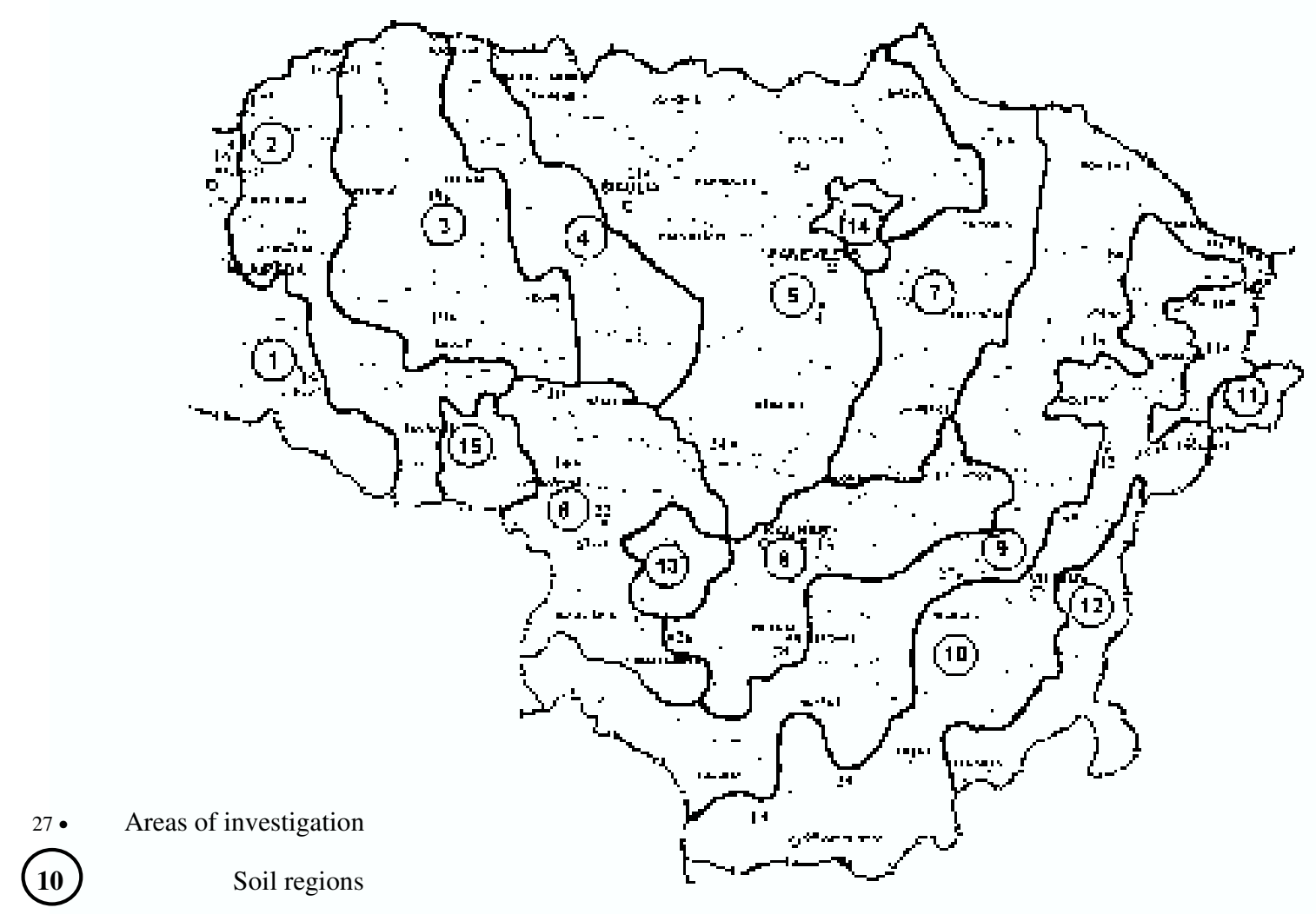

Fig 1. Investigation areas of agromonitoring in prevailing soils of different soil regions 
An average content of ${ }^{90} \mathrm{Sr}$ and ${ }^{137} \mathrm{Cs}$ was $3,0-7,0$ and $4,4-11,2 \mathrm{~Bq} \cdot \mathrm{kg}^{-1}$ respectively (Fig 2 ) in the layer of 0 $20 \mathrm{~cm}$ in control areas of radioactive contamination investigation. The ratio of ${ }^{137} \mathrm{Cs}$ and ${ }^{90} \mathrm{Sr}$ concentrations in the soil was $1,13-1,57$.
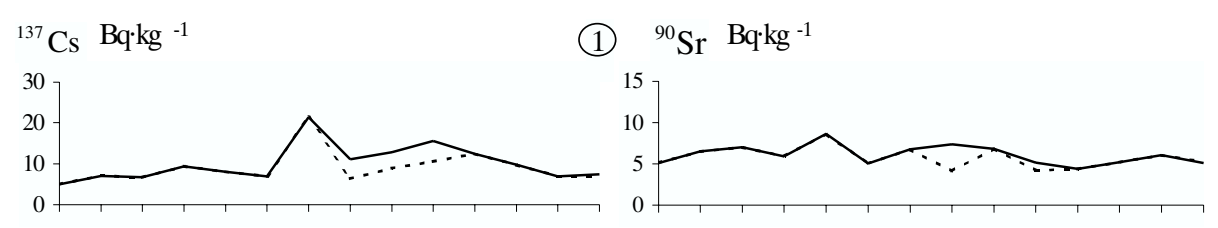

(2)
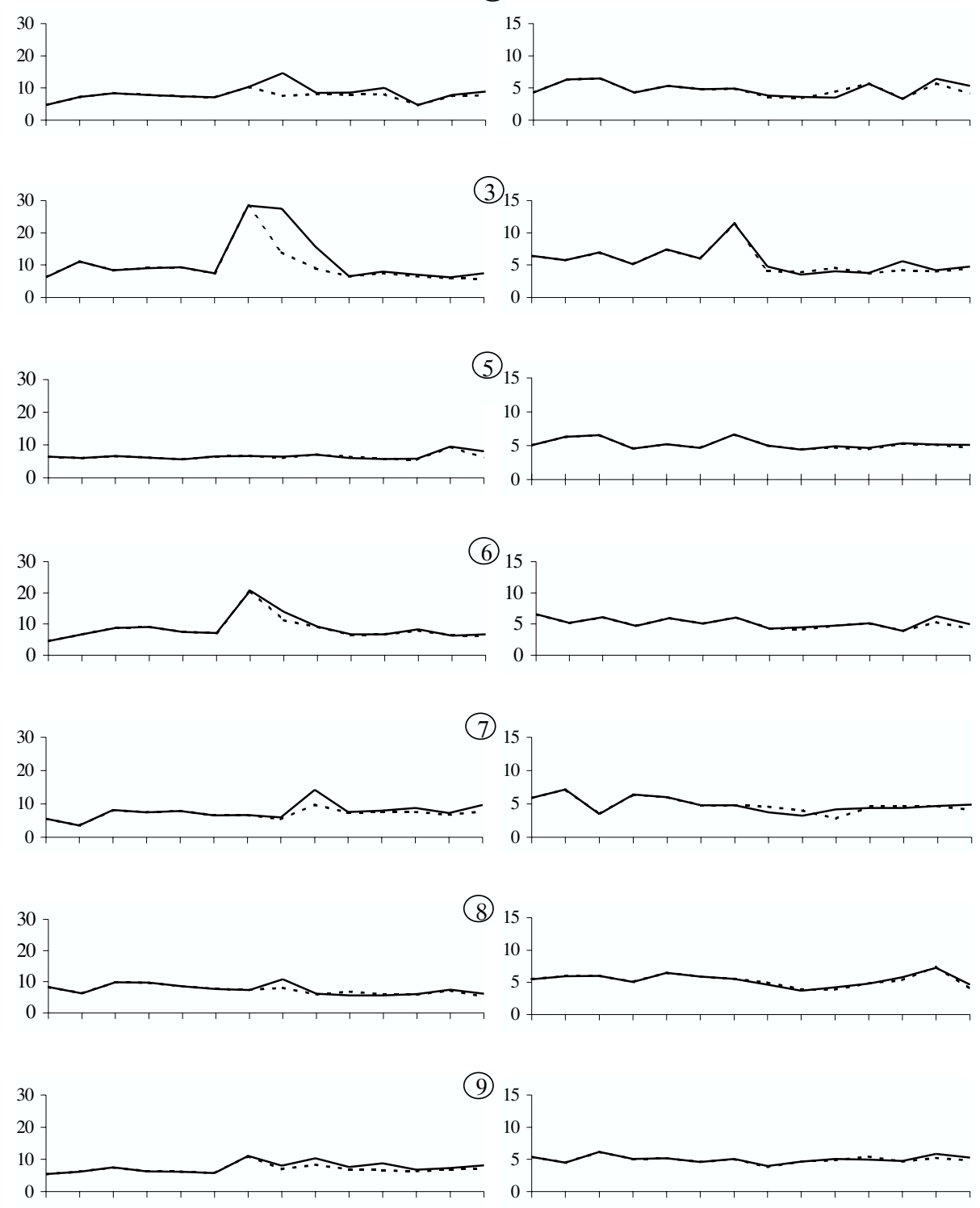

(10)
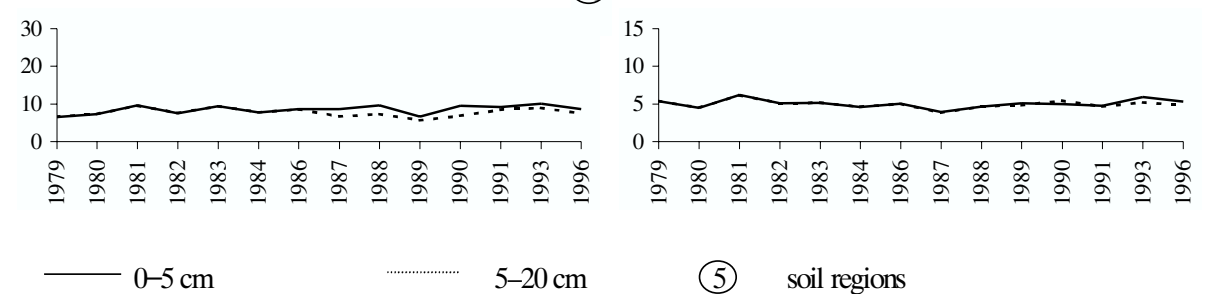

(5) soil regions

Fig 2. ${ }^{90} \mathrm{Sr}$ and ${ }^{137} \mathrm{Cs}$ in soils $(0-5,5-20 \mathrm{~cm})$ of different soil regions, $\mathrm{Bq} \cdot \mathrm{kg}^{-1}, 1979-1996$ 
According to the presented data, one can see that average concentrations of ${ }^{137} \mathrm{Cs}$ were higher in the southern, southwestern and southeastern parts of Lithuania, a little less - in central and eastern parts before the accident in the ChAPP. It should be noted that changes in regions $1-7$ of radionuclide concentrations were more significant than in regions $8-10$. For example, in plot 1 (Lazdijai region) the contamination by ${ }^{137} \mathrm{Cs}$ was $5,8 \mathrm{~Bq} \cdot \mathrm{kg}^{-1}$, next year $-13,2 \mathrm{~Bq} \cdot \mathrm{kg}^{-1}$; at that time in the plot 11 (Ignalina region) the soil contamination varied from 4,0 to $5,3 \mathrm{~Bq} \cdot \mathrm{kg}^{-1}$. There is a lower content of radionuclides in a sandy soil and sandy loam, a little higher - in clay and a loamy soil.

During the ChAPP accident on 26 April 1986 the air mass was moving in the north-western direction and approximately after one day it passed by West Lithuania, the Baltic Sea and reached the Scandinavian peninsula (Fig 3). The radionuclides were mostly in the state of dry precipitation over the territory of Lithuania [10].

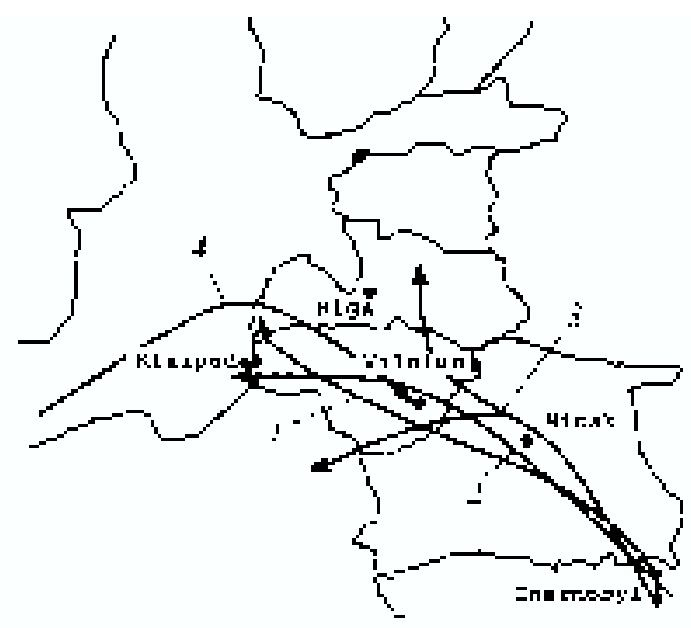

Fig 3. Air mass trajectory after the ChAPP accident on 26-30 April 1986
After the ChAPP accident the content of ${ }^{90} \mathrm{Sr}$ and ${ }^{137} \mathrm{Cs}$ in the soil was $2,6-7,1$ and $3,0-32,7 \mathrm{~Bq} \cdot \mathrm{kg}^{-1}$, respectively. So, the amount of ${ }^{90} \mathrm{Sr}$ in the layer of $0-20 \mathrm{~cm}$ of control plots did not change but the content of ${ }^{137} \mathrm{Cs}$ in some plots increased 4,5 times in comparison with the data of the previous several years. In some fields an average content of ${ }^{137} \mathrm{Cs}$ was $6,7-28,5 \mathrm{~Bq} \cdot \mathrm{kg}^{-1}$, that of ${ }^{90} \mathrm{Sr}$ was $4,9-11,56 \mathrm{~Bq} \cdot \mathrm{kg}^{-1}$. The largest radionuclide concentrations were detected in southeastern, southern and western regions of Lithuania.

Areas over which a cloud with radioactive substances passed were most contaminated by ${ }^{137} \mathrm{Cs}$. As D. Butkus, N. Lebedytė and other authors revealed, the released radionuclides spotted the ground surface. Contaminated "spots" concentrated intensively near forests and lakes and also in the hollows of flooded ground surface [11].

Radionuclide concentrations varied significantly and were determined by the place and depth of sampling. The largest concentrations were found at a depth of $0-5 \mathrm{~cm}$.

Radionuclide migration in the soil depends on the physical-chemical properties of radionuclides and also on the soil composition and state. Radionuclides mostly remain in the upper soil layers, their penetration into the soil is very slow, that is why even in places where precipitation is abundant radionuclide accumulation in deeper layers is taking place for many years.

In some spots of meadows and pastures the content of ${ }^{90} \mathrm{Sr}$ and ${ }^{137} \mathrm{Cs}$ in the upper soil layer of $0-5 \mathrm{~cm}$ was 1,04-1,28 times larger than in a layer of 5-20 cm, in southern and southwestern areas it was 1,38-1,88 times larger in comparison with a layer of $20-40 \mathrm{~cm}$.

Distribution of radionuclides taking into account the depth of individual areas in eastern, middle and western Lithuania is shown in Fig 4.

Distinctive differences in the content of ${ }^{137} \mathrm{Cs}$ in different soil layers and at a different time were found
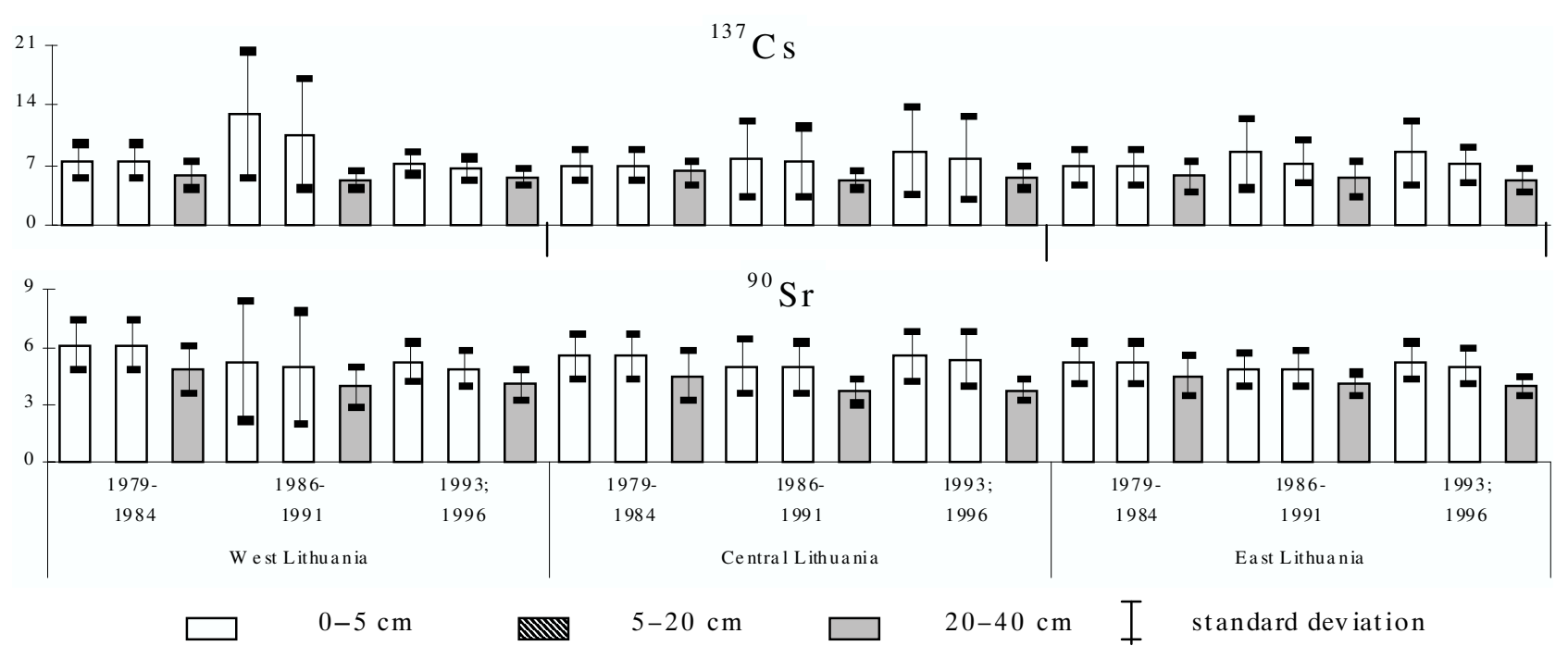

Fig 4. Distribution of ${ }^{90} \mathrm{Sr}$ and ${ }^{137} \mathrm{Cs}$ in the soils of western, central and eastern Lithuania $(0-5,5-20,20-40 \mathrm{~cm}) \mathrm{Bq} \cdot \mathrm{kg}^{-1}$ 
in the western region. The content of ${ }^{137} \mathrm{Cs}$ in the upper layer was 1,1-1,2 times larger than in a layer of 5-20 cm, and 1,3-2,5 times larger than in a layer of $20-40 \mathrm{~cm}$. Distinction is not so noticeable in middle and east Lithuania, correspondingly 1,1-1,2 and 1,2-1,6 times. ${ }^{137} \mathrm{Cs}$ is absorbed by the ground that is why its penetration into deeper layers is limited.

The content of ${ }^{90} \mathrm{Sr}$ in arable land in layers of $0-5$, $5-20 \mathrm{~cm}$ is also larger than in deeper layers and decreases $1,2-1,5$ times in a layer of $20-40 \mathrm{~cm}$.

An average content of ${ }^{90} \mathrm{Sr}$ and ${ }^{137} \mathrm{Cs}$ was $3,9-6,6$ and 5,5-14,3 $\mathrm{Bq} \cdot \mathrm{kg}^{-1}$, respectively, in separate plots during the period 1986-1991. A similar level was observed in 1993-1994 and in 1996. Increased amounts of ${ }^{90} \mathrm{Sr}$ and ${ }^{137} \mathrm{Cs}$ were not found near the Ignalina Atomic Power Plant.

The alluvial soils of the Nemunas valley, which is flooded every spring, is contaminated by various pollutants, harmful and radioactive substances.

According to the data of investigation in the
Nemunas delta, in the alluvial soils of the middle and upper parts of the Nemunas the content of ${ }^{137} \mathrm{Cs}$ is larger in the upper part (Miežiškiai, Alytus region), a little less - in the middle (Vilkija, Kaunas region) and the least - in the soils of the Nemunas delta (Table 1).

The amounts of ${ }^{137} \mathrm{Cs}$ and ${ }^{90} \mathrm{Sr}$ near the river bed and terrace are smaller than in alluvial soils in the middle part of the valley.

The content of ${ }^{90} \mathrm{Sr}$ in layers of $0-5$ and $5-20 \mathrm{~cm}$ is almost the same as at a depth of $20-40 \mathrm{~cm}$, except single cases. The content of ${ }^{137} \mathrm{Cs}$ in upper layers near the river bed and in soil layers of $0-5,5-20 \mathrm{~cm}$ in the central part of the valley is 1,3-3,2 times larger than at a depth of 20-40 cm.

According to the investigation data, the maps of ${ }^{90} \mathrm{Sr}$ and ${ }^{137} \mathrm{Cs}$ distribution in the Lithuanian soils were prepared. It is determined that before the ChAPP accident an average activity of ${ }^{137} \mathrm{Cs}$ and ${ }^{90} \mathrm{Sr}$ was $6,8 \pm 1,8$ and $5,3 \pm 1,2 \mathrm{~Bq} \cdot \mathrm{kg}^{-1}$, respectively. The radioactivity of peat soils was 2-5 times larger than that of mineral soils.

Table 1. ${ }^{137} \mathrm{Cs}$ and ${ }^{90} \mathrm{Sr}$ concentrations in various alluvial soils of the Nemunas valley in 1994

\begin{tabular}{|c|c|c|c|}
\hline \multirow{2}{*}{ Locality of sampling } & \multirow{2}{*}{ Depth of sampling, $\mathrm{cm}$} & \multicolumn{2}{|c|}{$\mathrm{Bq} \cdot \mathrm{kg}^{-1}$} \\
\hline & & ${ }^{137} \mathrm{Cs}$ & ${ }^{90} \mathrm{Sr}$ \\
\hline \multicolumn{4}{|c|}{ The upper Nemunas $\quad$ (Alytus distr, Miežiškiai) } \\
\hline 1. Near the river bed hapli-calcaric & $0-5$ & $6,6 \pm 1,3$ & $3,8 \pm 0,9$ \\
\hline fluvisols sand/sand & $5-20$ & $8,9 \pm 1,6$ & $5,0 \pm 0,8$ \\
\hline & $20-40$ & $4,9 \pm 1,0$ & $5,4 \pm 0,8$ \\
\hline 2. Central part of the valley & $0-5$ & $15,5 \pm 2,7$ & $5,3 \pm 0,7$ \\
\hline Orthientric fluvisols and endohypogleyi - & $5-20$ & $7,9 \pm 1,2$ & $5,2 \pm 0,9$ \\
\hline dystryc fluvisols sandy loam/ sandy loam & $20-40$ & $4,8 \pm 0,8$ & $4,7 \pm 0,7$ \\
\hline \multicolumn{4}{|c|}{ The middle Nemunas (Kaunas distr, Vilkija ) } \\
\hline \multirow{9}{*}{$\begin{array}{l}\text { 2. Central part of the valley } \\
\text { Orthientric fluvisols sandy loam/ sandy } \\
\text { loam } \\
\text { Orthientric fluvisols sandy loam/ loam }\end{array}$} & $0-5$ & $7,1 \pm 1,4$ & $3,2 \pm 1,0$ \\
\hline & $5-20$ & $6,5 \pm 1,3$ & $2,9 \pm 0,8$ \\
\hline & $20-40$ & $4,9 \pm 1,0$ & $3,8 \pm 0,9$ \\
\hline & $0-5$ & $9,8 \pm 1,8$ & $4,3 \pm 1,3$ \\
\hline & $5-20$ & $6,3 \pm 1,2$ & $5,8 \pm 1,4$ \\
\hline & $20-40$ & $6,0 \pm 1,0$ & $4,1 \pm 0,9$ \\
\hline & $0-5$ & $10,6 \pm 2,5$ & $4,8 \pm 0,8$ \\
\hline & $5-0$ & $9,3 \pm 1,7$ & $5,6 \pm 1,0$ \\
\hline & $20-40$ & $7,2 \pm 1,1$ & $6,2 \pm 1,1$ \\
\hline \multicolumn{4}{|c|}{ The Nemunas delta (Šilutès distr, Lumpėnai ) } \\
\hline 1. Near the river bed Hapli-calcaric & $0-5$ & $6,7 \pm 1,2$ & $4,4 \pm 1,0$ \\
\hline fluvisols sand/sand & $5-20$ & $6,2 \pm 1,2$ & $4,1 \pm 0,9$ \\
\hline & $20-40$ & $5,9 \pm 1,0$ & $3,1 \pm 0,5$ \\
\hline 2. Central part of the valley & $0-5$ & $9,5 \pm 1,6$ & $6,9 \pm 1,4$ \\
\hline Endohypogleyi - dystryc fluvisols & $5-20$ & $5,4 \pm 1,1$ & $3,9 \pm 1,0$ \\
\hline sandy loam/ sandy loam & $20-40$ & $4,5 \pm 1,0$ & $4,7 \pm 0,3$ \\
\hline 3. Near terrace soils & $0-5$ & $5,4 \pm 1,1$ & $4,7 \pm 1,0$ \\
\hline Endohypogleyi - dystryc fluvisols & $5-20$ & $5,1 \pm 1,0$ & $5,2 \pm 0,9$ \\
\hline sandy loam/ sandy loam & $20-40$ & $5,2 \pm 1,0$ & $4,1 \pm 0,4$ \\
\hline
\end{tabular}


The ${ }^{90} \mathrm{Sr}$ and ${ }^{137} \mathrm{Cs}$ migration from the soil to plants varies and depends on the soil properties (acidity, granulometric composition, carbonates, etc), meteorological conditions and the types of plants. After summarizing all the investigation data, average coefficients of the ${ }^{90} \mathrm{Sr}$ and ${ }^{137} \mathrm{Cs}$ migration from the soil to plants were established (Table 2).

According to the investigation data of 1979-1985, an

Table 2. Average coefficients of the ${ }^{90} \mathrm{Sr}$ and ${ }^{137} \mathrm{Cs}$ migration from the soil to plants, 1979-1985, 1996-1997

\begin{tabular}{|l|c|c|c|c|}
\hline \multirow{2}{*}{ Plants } & \multicolumn{2}{|c|}{${ }^{90} \mathrm{Sr}$} & \multicolumn{2}{c|}{${ }^{137} \mathrm{Cs}$} \\
\cline { 2 - 5 } & $1979-1985$ & $1996-1997$ & $1979-1985$ & $1996-1997$ \\
\hline $\begin{array}{l}\text { Crops: grain } \\
\text { straw }\end{array}$ & 0,37 & 0,29 & 0,36 & 0,17 \\
$\begin{array}{l}\text { Corn for } \\
\text { silage }\end{array}$ & 0,66 & 0,50 & 0,53 & 0,39 \\
$\begin{array}{l}\text { Mangel and } \\
\text { sugar beets }\end{array}$ & 0,46 & & 0,41 & \\
Carrots & 0,42 & & 0,41 & \\
Cabbages & 0,60 & & 0,35 & \\
Flax & 0,78 & & 0,31 & \\
Potatoes & 0,37 & 0,40 & 0,22 & \\
Annual grass & 0,56 & 0,68 & 0,42 & 0,40 \\
Perennial & 0,87 & 1,28 & 0,49 & 0,51 \\
grass & & & & \\
\hline
\end{tabular}

average content of ${ }^{90} \mathrm{Sr}$, characteristic of the reproductive part of plants (crops, carrots, potatoes), is $1,98-2,09 \mathrm{~Bq} \cdot \mathrm{kg}^{-1}$ and that of ${ }^{137} \mathrm{Cs}-2,26-2,58 \mathrm{~Bq} \cdot \mathrm{kg}^{-1}$. A little larger content of these elements was found in crop straw. The content of ${ }^{90} \mathrm{Sr}$ and ${ }^{137} \mathrm{Cs}$ in the perennial grass of meadow and pasture was 4,84 and $4,81 \mathrm{~Bq} \cdot \mathrm{kg}^{-1}$, respectively. Variations due to meteorological conditions and fertilization were observed within the limits of $1,3-12,47$ for ${ }^{90} \mathrm{Sr}$ and $0,74-10,96 \mathrm{~Bq} \cdot \mathrm{kg}^{-1}-$ for ${ }^{137} \mathrm{Cs}$.

After the ChAPP accident in 1986 the content of radionuclides in vegetative parts of perennial grass varied within broad limits: ${ }^{90} \mathrm{Sr}-8,1-439,4 \mathrm{~Bq} \cdot \mathrm{kg}^{-1}$, ${ }^{137} \mathrm{Cs}-20,0-2370,5 \mathrm{~Bq} \cdot \mathrm{kg}^{-1}$. Especially large amounts of isotopes were found in the grass of the first haymaking. According to the investigation data of 1986-1991, the content of ${ }^{90} \mathrm{Sr}$ in perennial grass increased 6,3 times in comparison with the data of $1979-1985$ and that of ${ }^{137} \mathrm{Cs}-$ 23,6 times. Besides, the content of ${ }^{137} \mathrm{Cs}$ increased 1,3 times in grain, 1,7 - in straw, 1,4 - in sugar beets. It is calculated that $43 \%$ of all the radioactive precipitation settled on plants and got into fodder. The largest concentration of both radionuclides was in 1986, then it was decreasing and in 1993-1994 it was close to the level of the period 1979-1985.

In most cases long-term fertilization had no significant influence on the ${ }^{90} \mathrm{Sr}$ and ${ }^{137} \mathrm{Cs}$ accumulation and migration in the soil (Table 3).

Table 3. Perpendicular migration of ${ }^{90} \mathrm{Sr}$ and ${ }^{137} \mathrm{Cs}$ in the soil in $1999-2000$

\begin{tabular}{|c|c|c|c|c|c|}
\hline Locality of sampling & Soil & Treatment & Depth, cm & ${ }^{137} \mathrm{Cs} \mathrm{Bq} \cdot \mathrm{kg}^{-1}$ & ${ }^{90} \mathrm{Sr} \mathrm{Bq} \cdot \mathrm{kg}^{-1}$ \\
\hline \multirow{8}{*}{$\begin{array}{c}\text { Vilkaviškis district } \\
\text { Rumokai }\end{array}$} & \multirow{8}{*}{$\begin{array}{c}\text { Limnoglace } \\
\text { silty Calc(ar)I- } \\
\text { Epihypogleyic } \\
\text { Luvi soil }\end{array}$} & \multirow[t]{4}{*}{$\mathrm{N}_{0} \mathrm{P}_{0} \mathrm{~K}_{0}$} & $0-20$ & $7,1 \pm 1,1$ & $5,5 \pm 0,8$ \\
\hline & & & $20-40$ & $5,0 \pm 0,8$ & $4,1 \pm 0,6$ \\
\hline & & & $40-60$ & $4,1 \pm 0,6$ & $3,3 \pm 0,5$ \\
\hline & & & $60-90$ & $4,0 \pm 0,6$ & $2,5 \pm 0,4$ \\
\hline & & \multirow{4}{*}{$\mathbf{N}_{180} \mathbf{P}_{180} \mathbf{K}_{180}$} & $0-20$ & $8,6 \pm 1,3$ & $6,0 \pm 0,9$ \\
\hline & & & $20-40$ & $6,6 \pm 1,0$ & $3,5 \pm 0,5$ \\
\hline & & & $40-60$ & $4,2 \pm 0,6$ & $1,8 \pm 0,3$ \\
\hline & & & $60-90$ & $3,7 \pm 0,6$ & $2,4 \pm 0,4$ \\
\hline \multirow{8}{*}{$\begin{array}{l}\text { Radviliškis district } \\
\text { Skèmiai }\end{array}$} & \multirow{8}{*}{$\begin{array}{c}\text { Endocalcari- } \\
\text { Endohypogleyic } \\
\text { Cambi soil }\end{array}$} & \multirow[t]{4}{*}{$\mathrm{N}_{0} \mathrm{P}_{0} \mathrm{~K}_{0}$} & $0-20$ & $6,3 \pm 0,9$ & $5,8 \pm 0,9$ \\
\hline & & & $20-40$ & $4,3 \pm 0,6$ & $5,8 \pm 0,9$ \\
\hline & & & $40-60$ & $3,8 \pm 0,6$ & $2,5 \pm 0,4$ \\
\hline & & & $60-90$ & $3,6 \pm 0,5$ & $1,8 \pm 0,3$ \\
\hline & & \multirow[t]{4}{*}{$\mathbf{N}_{240} \mathbf{P}_{192} \mathbf{K}_{192}$} & $0-20$ & $7,6 \pm 1,1$ & $7,2 \pm 1,1$ \\
\hline & & & $20-40$ & $4,2 \pm 0,6$ & $4,2 \pm 0,6$ \\
\hline & & & $40-60$ & $4,2 \pm 0,6$ & $4,9 \pm 0,7$ \\
\hline & & & $60-90$ & $3,9 \pm 0,6$ & $2,2 \pm 0,3$ \\
\hline \multirow{8}{*}{$\begin{array}{c}\text { Šakiai district } \\
\text { Kriūkai }\end{array}$} & \multirow{8}{*}{$\begin{array}{c}\text { Endocalcari- } \\
\text { Endohypogleyic } \\
\text { Cambi soil }\end{array}$} & \multirow[t]{4}{*}{$\mathrm{N}_{0} \mathrm{P}_{0} \mathrm{~K}_{0}$} & $0-20$ & $6,7 \pm 1,0$ & $5,2 \pm 0,8$ \\
\hline & & & $20-40$ & $4,6 \pm 0,7$ & $5,1 \pm 0,8$ \\
\hline & & & $40-60$ & $4,0 \pm 0,6$ & $2,5 \pm 0,4$ \\
\hline & & & $60-90$ & $3,8 \pm 0,6$ & $2,0 \pm 0,3$ \\
\hline & & \multirow[t]{4}{*}{$\mathbf{N}_{120} \mathbf{P}_{180} \mathbf{K}_{180}$} & $0-20$ & $6,8 \pm 1,0$ & $4,8 \pm 0,7$ \\
\hline & & & $20-40$ & $5,5 \pm 0,8$ & $4,0 \pm 0,6$ \\
\hline & & & $40-60$ & $4,0 \pm 0,6$ & $2,2 \pm 0,3$ \\
\hline & & & $60-90$ & $2,9 \pm 0,4$ & $2,3 \pm 0,3$ \\
\hline
\end{tabular}


In a single variant where fertilization with $\mathrm{N}_{240} \mathrm{~N}_{192}$ $\mathrm{K}_{192}$ was used, the concentration of ${ }^{90} \mathrm{Sr}$ and ${ }^{137} \mathrm{Cs}$ increased 1,2 time in comparison with that without fertilization. It was observed only in the Skemiai trial.

\section{Conclusions}

1. It is determined that an average activity of ${ }^{137} \mathrm{Cs}$ was $6,8 \pm 1,8 \mathrm{~Bq} \cdot \mathrm{kg}^{-1}$, and that of ${ }^{90} \mathrm{Sr}-5,3 \pm 1,2 \mathrm{~Bq} \cdot \mathrm{kg}^{-1}$. The radioactivity of peat soils was $2-5$ times larger than that of mineral soils.

2. The amounts of ${ }^{90} \mathrm{Sr}$ and ${ }^{137} \mathrm{Cs}$ in the soil after the ChAPP accident were 2,6-7,1 and 3,0-32,7 $\mathrm{Bq} \cdot \mathrm{kg}^{-1}$, respectively. So, the amount of ${ }^{90} \mathrm{Sr}$ in control plots the layer of $0-20 \mathrm{~cm}$ did not change, but the content of ${ }^{137} \mathrm{Cs}$ in some plots increased 4,5 times in comparison with the data of the previous several years. The largest radionuclide concentrations were detected in the southeastern, southern and western regions of Lithuania.

3. The content of ${ }^{137} \mathrm{Cs}$ in the upper layers in the western region was 1,1-1,2 times larger than in the layer of 5-20 cm and 1,3-2,5 times larger than in the layer of 20-40 cm. Distinction was not so noticeable in middle and eastern Lithuania, correspondingly 1,1-1,2 and $1,2-1,6$ times.

4. Migration of ${ }^{90} \mathrm{Sr}$ and ${ }^{137} \mathrm{Cs}$ from the soil to plants varies and depends on the soil properties and the type of plants. The coefficients of the ${ }^{137} \mathrm{Cs}$ and ${ }^{137} \mathrm{Cs} \mathrm{mi-}$ gration from the soil to plants were $0,24-0,53$ and $0,37-0,87$, respectively.

5. In most cases long-term fertilization had no significant influence on the ${ }^{90} \mathrm{Sr}$ and ${ }^{137} \mathrm{Cs}$ accumulation and migration in the soil.

\section{References}

1. Cambray, R. S. and others. Radioactive fallout in air and rain: results to the end of 1989. London: UKAEA Report AERE -R 13575, HMSO.

2. Izrael, J. A. and others. Atlas of the Radionuclides Pollution of Europe by ${ }^{137} \mathrm{Cs}$ after the Chernobyl Accident. Journal Meteorology and Hydrology (Метрология и гидрология), No 1986, 4, p 8-17 (in Russian).

3. Butkus, D and others. ${ }^{137} \mathrm{Cs}$ and ${ }^{90} \mathrm{Sr}$ in the Soils of Lithuania. Journal Geochemistry International (Геохимия). Vol 39, No 7, 2001, p 719-724.

4. Mažeika, J. and others. Arial Distribution of Technogenic Radionuclides in Soils of Ignalina NPP Region and Their Geophysical Evaluation. Environmental Engineering (Aplinkos inžinerija) Vol VI, No 1, 1998, p 18-26 (in Lithuanian).

5. Askbrant, S. Mobility of radionuclides in undisturbed and cultivated soils in Ukraine, Belarus and Russia six years after the Chernobyl fallout. Environmental Radioactivity, Vol 31, No 3, 1996, p 287-312.

6. Aleksakhin, R. M. Ten Years after Chernobyl: Results of Investigations on Radioecology. Radiation. Biology: Radioecology (Радиационная биология. Радиоэкология), Vol 36, 4, p 451-459 (in Russian).
7. Bakunov, N. A. From Global ${ }^{90} \mathrm{Sr}$ of Soil to Radiologic Evaluation of its Behavior and Transportation. Agrochemistry (Агрохимия), No 1, 1988, p 85-92 (in Russian).

8. Ruhm, W. and others. Migration of ${ }^{137} \mathrm{Cs}$ and ${ }^{90} \mathrm{Sr}$ in different forest soil layers. Environmental Radioactivity, Vol 38, No 1, 1996, p 63-75.

9. Methodical Instructions on the Determination of Strontium90 and Cesium-137 in Soils and Plants. Moscow, 1985 (in Russian).

10. Galvonaite, A. Analysis of Meteorological Conditions in Lithuania after the Chernobyl NPP Accident. Atmosphere Physics (Физика атмосферы), Vol 14, 1989, p 11-19 (in Russian).

11. Butkus, D. and others. Radionuclides in Environment. Ecological Sustainability of Lithuania Historical Context (Radionuklidai aplinkoje. Lietuvos ekologinis tvarumas istoriniame kontekste). Vilnius: Mokslas, 1999, p 120-160 (in Lithuanian).

\section{RADIONUKLIDU MIGRACIJA ARIAMUOSE LIETUVOS DIRVOŽEMIUOSE}

\section{J. Lubytė, A. Antanaitis}

Santrauka

Pateikti 1974-2000 m. atliktų skirtingų Lietuvos klimatinių ir gamtinių zonų i̇vairios dirvožemio granuliometrinès bei mineraloginès, taip pat uolienų mineraloginès sudèties laukų dirvožemių užterštumo ${ }^{137} \mathrm{Cs}$ ir ${ }^{90} \mathrm{Sr}$ tyrimo duomenys. Aptarti šių elementų susikaupimo, vertikaliojo pasiskirstymo ir migracijos $\mathfrak{i}$ augalus iki Černobylio AE avarijos ir po jos duomenys, radionuklidų kiekių priklausomybè nuo ilgalaikio tręšimo įvairiomis NPK trąšų normomis, radionuklidų perèjimo į augalus koeficientai.

Nustatyta, kad iki Černobylio AE avarijos ${ }^{137} \mathrm{Cs}$ vidutinis aktyvumas vyraujančiuose Lietuvos dirvožemiuose buvo $6,8 \pm$ $1,8 \mathrm{~Bq} \cdot \mathrm{kg}^{-1}, \quad$ o ${ }^{90} \mathrm{Sr}-5,3 \pm 1,2 \mathrm{~Bq} \cdot \mathrm{kg}^{-1}$. Durpinių dirvožemių radioaktyvumas $-2-5$ kartus didesnis negu šalies mineraliniu dirvožemių. Po Černobylio atominès elektrinès avarijos ${ }^{90} \mathrm{Sr}$ kiekis dirvožemyje $1986 \mathrm{~m} .0-20 \mathrm{~cm}$ sluoksnyje pakito nežymiai. Kai kurių rajonų dirvožemiuose ${ }^{137} \mathrm{Cs}$ vidutiniškai nustatyta $6,7-28,5 \mathrm{~Bq} \cdot \mathrm{kg}^{-1}$. Didesnès radionuklidų koncentracijos dirvožemyje aptiktos pietrytiniuose, pietiniuose ir vakariniuose Lietuvos rajonuose.

Viršutiniame $(0-5 \mathrm{~cm})$ dirvožemio sluoksnyje Vakarų zonoje ${ }^{137} \mathrm{Cs}$ buvo $1,1-1,2$ karto daugiau negu 5-20 cm sluoksnyje ir 1,3-2,5 karto daugiau negu $20-40 \mathrm{~cm}$ sluoksnyje. Vidurio ir Rytų Lietuvos zonose skirtumai atitinkamai 1,1-1,2 ir 1,2-1,6 karto mažesni.

${ }^{90} \mathrm{Sr}$ ir ${ }^{137} \mathrm{Cs}$ perèjimas iš dirvožemio i augalus vyksta nevienodai ir priklauso nuo dirvožemio savybių bei auginamu augalų. ${ }^{90} \mathrm{Sr}$ perèjimo iš dirvožemio į augalus koeficientai buvo $0,37-0,87$, o ${ }^{137} \mathrm{Cs}-0,22-0,53$.

Ilgametis tręšimas mineralinèmis trąšomis daugeliu atvejų didesnès įtakos ${ }^{90} \mathrm{Sr}$ ir ${ }^{137} \mathrm{Cs}$ kaupimuisi dirvožemyje neturèjo.

Raktažodžiai: dirvožemis, radionuklidai, ${ }^{137} \mathrm{Cs},{ }^{90} \mathrm{Sr}$, migracija, Černobylio AE. 
МИГРАЦИЯ РАДИОНУКЛИДОВ В ПАХОТНЫХ ПОЧВАХ ЛИТВЫ

\section{Я. Лубите, А. Антанайтис}

\section{Р ез ю м е}

Представлены данные 1974-2000 г.г. по загрязнению разных по гранулометрическому и минералогическому составу почв различных природных и климатических зон сельскохозяйственных угодий Литвы. Обобщены данные по содержанию и миграции радионуклидов по профилю почв, а также накопление их в урожае растительной продукции. Изучено влияние длительного систематического применения высоких доз NPK на загрязнение почв радионуклидами.

Установлено, что до катастрофы на Чернобыльской АЭС удельная активность ${ }^{137} \mathrm{Cs}$ в преобладающих пахотных почвах Литвы была $6,8 \pm 1,2$, а ${ }^{90} \mathrm{Sr}-5,3 \pm 1,2$ Бк'кГ ${ }^{-1}$. Радиоактивность торфяных почв была в 2-5 раз выше, чем минеральных. Загрязненность территории Литвы ${ }^{90} \mathrm{Sr}$ после катастрофы на Чернобыльской АЭС изменилась незначительно. Более значительно этим радионуклидом были загрязнены лишь отдельные места. Концентрация цезия в отдельных почвенных районах колебалась от 6,7 до 28,5 Бк кг $^{-1}$. Повышенные концентрации радионуклидов обнаружены в почвах юго-восточных, южных и западных районов Литвы.

В поверхностном слое почвы (0-5 см) Западной зоны Литвы ${ }^{137} \mathrm{Cs}$ было в 1,1-1,2 раза больше, чем в слое в $5-20$ см, и в $1,3-2,5$ раза больше, чем в слое в $20-40$ см. В Средней и Восточной зонах Литвы концентрации различались меньше - соответственно в $1,1-1,2$ и 1,2-1,6 раза.

Коэффициенты накопления радионуклидов зависят от типа почв и вида растений. Коэффициенты накопления ${ }^{137} \mathrm{Cs}$ в растениях колеблются в пределах $0,24-0,53$, a ${ }^{90} \mathrm{Sr}-$ $0,37-0,87$.

Длительное систематическое применение различных норм удобрений практически не оказало влияния на содержание и миграцию радионуклидов в почве.

Ключевые слова: почва, радионуклиды, ${ }^{137} \mathrm{Cs},{ }^{90} \mathrm{Sr}$, миграция, Чернобыльская АЭС. 